\title{
Observations on plant development (VII) The development of some perennial plants
}

\author{
A. LISTOWSKI, I. JACKOWSKA
}

\section{INTRODUCTORY REMARKS}

1. In continuation of experiments on the development of plants in dependence of varying light conditions partly also of low temperature treatment, successive observations were carried out with 24 biennials and perennials species.

Bi e nni a ls: Arctium minus, Daucus carota, Tragopogon pratensis and Verbascum thapsiforme.

P e rennials: Betonica officinalis, Centaurea jacea, Chelidonium maius, Cichorium intybus, Cucubalus baccifer, Dianthus carthusianorum, Heracleum sphondylium, Nepeta cataria, Plantago lanceolata, Polemonium coeruleum, Potentilla anserina, Potentilla supina, Potentilla reptans, Ranunculus repens, Rumex acetosella, Rumex obtusifolius, Salvia sclarea, Salvia pratensis, Taraxacum officinale, Valeriana officinalis. The time of observation varied, extending often over a few years. Some species were observed in several series sown at various dates.

2. Experiments with some species were carried out in a glasshouse (temperature never below $13-15^{\circ}$ ), from 1962 also in growth rooms (temperature 22-24). In winter the plants were growing the whole time in those rooms, in summer they were transported outside for a definite number of hours under day light.

The plants were grown under var:ous daylengths: short day $\left(S_{8}\right)$, continuous $\left(L_{24}\right)$, also by some species long day $\left(L_{16}\right)$ or under daylight of normally varying length $(N)$.

Short day conditions: 8 hours daylight or only during winter artificial light (7-8 thousand lux from fluorescent lamps).

$L_{16}$ and $L_{24}$ : Daylight plus artificial illumination of $6-8$ thousand lux (at night) or (during winter in the growth room) only artificial light.

In spite of daylength being the controlled factor, the differences in development cannot be interpreted as solely a response to this factor, for light conditions underwent cyclic seasonal changes, as regards intensity and spectral composition.

Thus, strictly speaking, the data reported are results of observations 
made under various, seasonally changing light conditions at a constant ratio of day to night $\left(S_{8}\right),\left(L_{16}\right),\left(L_{24}\right)$. Such an approach is the more justified, if it is considered that generally not only the daylength, but the interaction between it and light intensity, on one hand and its spectral composition, on the other, influence significantly the time and rate of flowering as well as the frequency of flowering (number of plants coming into bloom within the population under investigation).

The differences in the frequency of flowering which are the expression of individual variation, increase sometimes considerably in conditions non-optimal for generative development. This appeared to the authors of particular interest.

It was frequently observed that even the direction of the changes in the light conditions ("rising" from mid winter, "waning" from mid summer) exerts a significant influence.

In some species an aftereffect of the illumination conditions, under which the plants developed in their early stages, was distinctly recognizable.

The influence of low temperature on some species (natural vernalization) exposed to various light conditions before and after vernalization was investigated.

In the observations careful account was taken of the differences in vegetative development and of the ,variation of growth activity" (including the periods of rest distinctly observable in some species).

The group of analyzed species proved extremely heterogenous as far as the dependence of their generative development on light and temperature conditions is concerned, involving a wide range from more or less neutral species to those exhibiting distinct developmental differences in dependence on the length of the photoperiods. If the influence of temperature is considered, here too wide variations in reactions may be observed, ranging from species in which "normal" development is dependent on the influence of low temperature in a rather "obligatory" way, through species with facultative reactions, to neutral ones.

Some cases were also observed in which the vernalization treatment was "obligatory" under definite light conditions some others in which the influence of vernalization was revealed only in a more intensive flowering.

The present observations are reported for some species in abbreviated form, more details are only given for those, whose reaction seemed more complex and interesting.

The results will be communicated in successive publications in which plants with similar reactions are grouped together, a general discussion of results and of some special problems is put off, to the last publication of the series. 
Potentilla anserina. Flowers under natural conditions V-VIII. A common cosmopolitan species of a very wide area.

The initial plants had been obtained from the rosettes on the runners. Observations carried out under continuous daylight $\left(L_{24}\right)$ and under short day $\left(S_{8}\right)$ beginning from September 1960 up to the middle of the year 1963 .

\begin{tabular}{|c|c|c|c|}
\hline & $\begin{array}{l}\text { Years } \\
\text { Months }\end{array}$ & $I_{24}$ & $\mathrm{~S}_{8}$ \\
\hline \begin{tabular}{l}
8 \\
$\stackrel{6}{1}$ \\
\hdashline
\end{tabular} & XII & $\begin{array}{l}\text { Rosettes of 10-12. leaves } \\
\text { Leaves distinotly larger } \\
\text { The oldest leaves d1e away, }\end{array}$ & $\begin{array}{l}\text { Rosettes of 8-11 leaves } \\
\text { Leaves distinctly smaller } \\
\text { Rap1d dy1ng away of all }\end{array}$ \\
\hline \multirow{5}{*}{ Бே } & $I I-I I I$ & $\begin{array}{l}\text { tiation of the young leaves } \\
\text { Development of the new } \\
\text { leaves and slightly later } \\
\text { of the runners } \\
\text { On the average } 6-8 \text { leaves, } \\
6-8 \text { runners. Beginning of } \\
\text { flowering }\end{array}$ & $\begin{array}{l}\text { On the average 8-9 leaves } \\
\text { In the rosette }\end{array}$ \\
\hline & $\begin{array}{l}\mathrm{V} \\
\mathrm{VI}\end{array}$ & Intense flowering & $\begin{array}{l}\text { Intense development of leaves, } \\
\text { slight one of runners (on the } \\
\text { average 2-4) flowering }\end{array}$ \\
\hline & VIII & Plowerlng over & Flowering over \\
\hline & IX & Sl1ght second flowerling & Beglnning of leaf w'lting \\
\hline & $X I I$ & Growth stagnation & Phase of full rest \\
\hline \multirow{4}{*}{$\begin{array}{l}\text { No } \\
\stackrel{5}{\leftarrow}\end{array}$} & $I, I I, I I I$ & $\begin{array}{l}\text { Development of the new } \\
\text { leaves and runners }\end{array}$ & Development of a new rosette \\
\hline & $\mathrm{V}, \mathrm{VI}$ & $\begin{array}{l}\text { Intense vegetative } \\
\text { development }\end{array}$ & Flower1ng \\
\hline & VII, VIII & Intense flowering & $\begin{array}{l}\text { Fall of flowers, second slight } \\
\text { development of leaves }\end{array}$ \\
\hline & $X I, X I I$ & $\begin{array}{l}\text { Growth stagnation and partial } \\
\text { dy1ng away of leaves }\end{array}$ & $\begin{array}{l}\text { Dy 1ng away of leaves. Phase } \\
\text { of rest }\end{array}$ \\
\hline \multirow{5}{*}{ ڤั } & I & . & \\
\hline & IV $-\mathrm{V}$ & Flowerling & Sporad1c flowering \\
\hline & VI & $\begin{array}{l}\text { No flowers, intense growth } \\
\text { of the runners }\end{array}$ & No flowers \\
\hline & VII & . & Abundant flovering \\
\hline & VIII & Intense llowerlng & \\
\hline
\end{tabular}


Consequently:

1. There is a distinct cyclic recurrence in the development - especially under the short day where the plants pass every year a phase of full rest lasting about $6-8$ weeks.

2. The development of runners distinctly more vigorous under the continuous daylight.

3. The flowering intensity shows a certain connection with the quantity of light. Under the short day the flowering max:mum occurs in the periods of maximal light intensity, under the continuous one somewhat later (VIII) or earlier (IV-V).

Ranunculus repens - a perennial plant, flowering VI-VIII. Observations were carried out during $2^{1 / 2}$ years on a small number of plants sown in February and September, and besides this on several runner rosettes, planted from the short day plants.

Combination $L_{24}$ - intense vegetative development during all the summer - at the same time the runners small number of flower buds on the plants sown in February and in late autumn. On the plants from rosettes a small number in January and February of the next year and abundant flowering from August.

Com bin a tion $S_{8}$ - sowing in February, vegetative develcpment all the year. In April budding and then flowering to August. In autumn a partial dying away of leaves and not rcoted runners. In the second year flowering III-VI. Plants from runner rosettes vegetative develcpment all the year with weaker development of runners in autumn period of stagnation - in the second half of winter (2nd year of vegetation) an intense development of runners and then (IV-VI) flowering.

Similarly the plants sown in September began to flower in late spring of the second year.

So the plant flowers both under the continuous daylight, and under the short day. The cycles of flowering, development of runners and leaves occur, however, in different months.

Under the continuous daylight the plants flower twice in the end of summer more intensely, in the second half of winter in a lower degree, it indicates an interaction with the light intensity.

Intense development of the leaves and runners - spring and summer.

Under the short day flowering in the period of late spring and summer, preceded by a phase of intense differentiation of the leaves and runners.

Maximum of flowering under the continuous daylight occurs in the periods of diminishing light regimes - under the short day in the increasing ones.

It may be considered also, that if the plant passes its juvenile stage in autumn, its passing into generative phase becomes retarded, inde- 
pendently of the daylength under which the plant grows afterwards.

Under the continuous daylight the leaves are somewhat larger, petioles long and the flowering intensity higher.

Cucubalus baccifer - perennial plant. Time of flowering in field conditions June - August.

Observations made within the period 1959-1963 on three series.

I series: seeding Aug. 31, 1959, germination Sept. 15. After the first pair of leaves was formed the seedlings were placed under a) continuous light and b) 8-hrs day (in hothouse).

1 a b 1 e 1

\begin{tabular}{|c|c|c|c|c|c|c|c|c|c|c|}
\hline \multirow{3}{*}{$\begin{array}{l}\text { No. of } \\
\text { days } \\
\text { after } \\
\text { germ1- } \\
\text { nation }\end{array}$} & \multicolumn{5}{|c|}{$\mathrm{s}_{8}$} & \multicolumn{5}{|c|}{$\mathrm{L}_{24}$} \\
\hline & \multirow{2}{*}{$\begin{array}{c}\text { Yean } \\
\text { he1ght }\end{array}$} & \multirow{2}{*}{$\begin{array}{c}\text { Mean } \\
\text { no.or } \\
\text { leaves }\end{array}$} & \multicolumn{3}{|c|}{$\begin{array}{c}\text { Length } x \text { width } \\
\text { of blade }\end{array}$} & \multirow{2}{*}{$\begin{array}{c}\text { Mean } \\
\text { he1ght }\end{array}$} & \multirow{2}{*}{$\begin{array}{l}\text { Mean } \\
\text { no. of } \\
\text { leaves }\end{array}$} & \multicolumn{3}{|c|}{$\begin{array}{l}\text { Length } x \text { width } \\
\text { of lamina }\end{array}$} \\
\hline & & & $\stackrel{I}{\text { pair }}$ & $\underset{\text { pa1r }}{\text { II }}$ & $\begin{array}{l}\text { III } \\
\text { pa1r }\end{array}$ & & & pa1r & $\begin{array}{c}\text { II } \\
\text { pa1r }\end{array}$ & $\begin{array}{c}\text { III } \\
\text { paIr }\end{array}$ \\
\hline 34 & \multirow{4}{*}{ 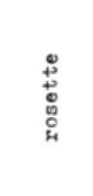 } & 6 & 4.3 & 3.8 & 0 & 2.8 & 8 & 11.9 & 10.9 & 6.9 \\
\hline 49 & & 8 & 5.2 & 6.8 & 3.8 & 4.7 & 10 & 11.8 & 13.6 & 18.4 \\
\hline 79 & & 9 & 5.2 & 7.0 & 5.8 & 13.3 & 22 & 11.9 & 15.6 & 22.6 \\
\hline 115 & & 11 & - & - & - & 54.8 & 33 & - & - & - \\
\hline
\end{tabular}

The results of observation of vegetative development in the course of the first 115 days are tabulated (Table 1). The leaf lamina differentiates and grows much quicker under continuous illumination.

These differences subsisted in further vegetative development. In $L_{24}$ - rapid stem elongation, some plants reach a height of $1 \mathrm{~m}$. Intensive development of side shoots.

After 160 days - end of March - two of the ten plants flowered. In the course of the following three weeks all the plants were in bloom. Very intensive florescense. Period of blossoming longer, florescence more intensive than under field conditions.

$S_{8}$ : small rosette with very slowly differentiating and growing leaves in the course of the whole autumn and winter season. Only towards spring (end of March) quicker development with simultaneous dying of "automn" leaves. Leaves smaller than under $L_{2 / 4}$.

In July after 270 days the majority of plants developed thick densely foliated stems $10-20 \mathrm{~cm}$ high. Side shoots also developed. 
In late autumn (Oct. - Nov.) the leaves began dying from below, the development of new leaves was going down and ceased, and the shoots died. End of December most shoots dead - short phase of dormancy and new rosettes start to develop from auxiliary buds. May (570 days after germination) new rosettes fully developed, leaves distinctly larger than the "autumn" ones, stem began to elongate. Shoots much more sturdy than under $L_{24}$ thickly foliated. Leaves thicker, "fleshy". End of August.

2nd year of life (660 days) the majority of plants buds and comes into flower.

Florescence less intensive under $S_{8}$ under $L_{24}$.

Habit of the plants in $L_{24}$ and $S_{8}$ different from that of plants growing on field.

In autumn 1960 - 386 days after germination part of the plants from $S_{8}$ were transferred to $L_{24}$ at the phase of "dormancy" and dying of shoots. Soon after they had been transfered, a rapid development of new rosettes started from the auxiliary buds on the shoots. Profuse florescence occurred 612 days from germination, 226 days from transfer.

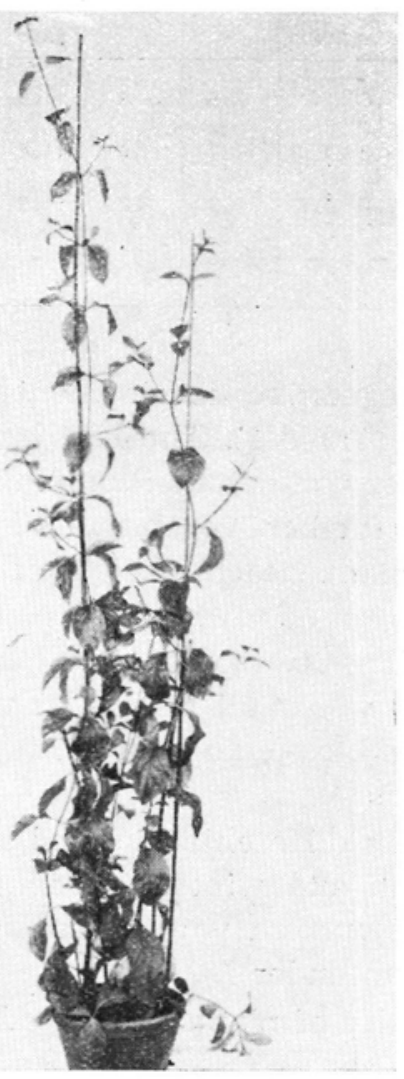

Photo 1. Cucubalus baccifer (15.II.60). Plants in continuous light. 
The vegetative development of these plants was more intensive as compared with that of plants growing the whole timer under $L_{24}$.

Series II: seeded in August 1961. Seeds from plants which flowered and bore seeds in the glasshouse in $L_{24}$. October 4,1961 , seedlings

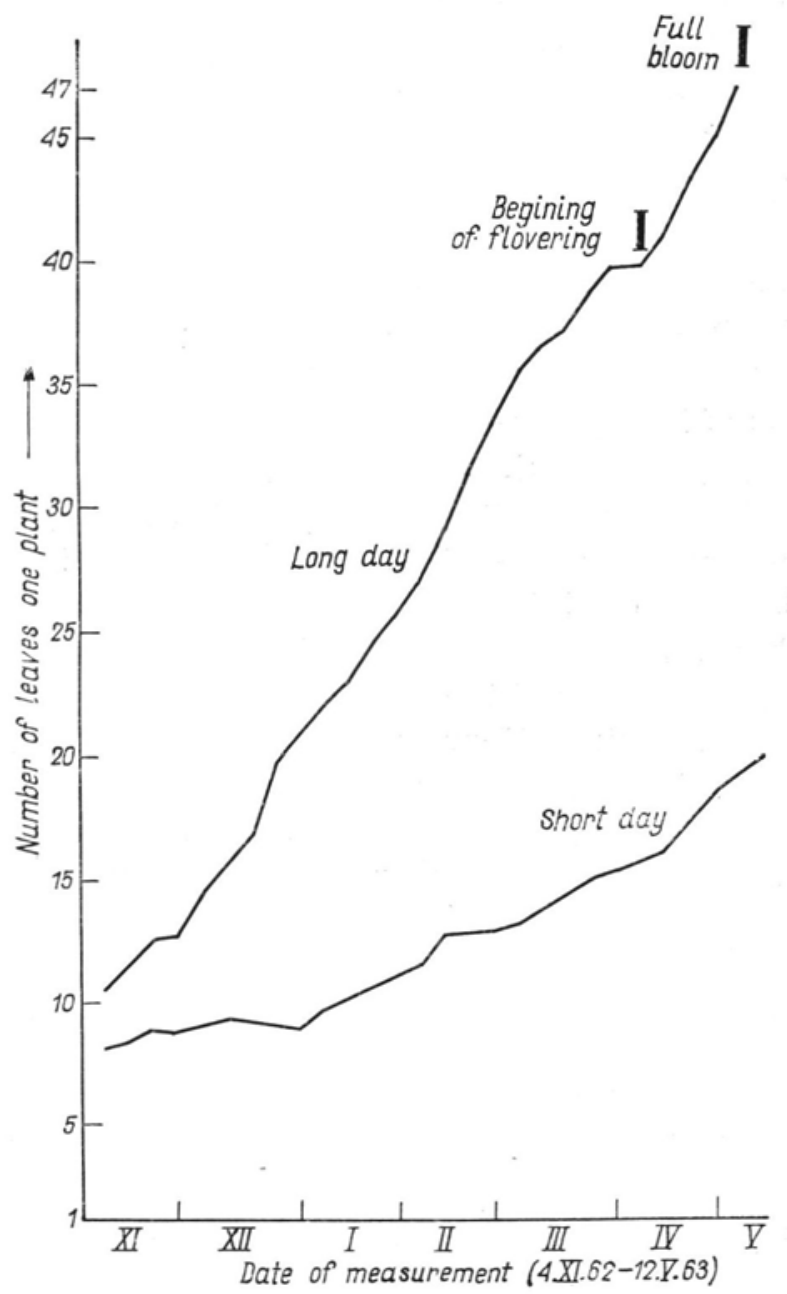

Fig. 1. Number of leaves on one plant of Cucubalus baccifer.

with 2 leaves (29 days after germination) placed under $L_{24}$ and $S_{8}$. The number of leaves was counted at weekly intervals from November 4 to full bloom under $L_{24}$ (190 days). The results plotted on the graph show considerable difference in the rate of growth of leaves. Under $L_{24}$ it is continuous, while under short day it is accelerated in spring.

$L_{24}$. Development of plants analogous to that in series I. After a very short rosette phase - development of shoots (75 days after germination). 
Budding in April, general florescence in mid May (ca 236 days after germination).

$S_{8}$. Small rosette developing very slowly in late autumn and winter. Growth intensified in early spring (March, April).

In July, similarly as in plants of series I, extension growth of shoots. Shoots very densely foliated with short internodes.

Number of leaves mean 32.6 - variation $19-46$

Height of plants mean 24.1 - variation $11.5-62 \mathrm{~cm}$

End of August (336 days) two plants with flower buds.

Up to Oct. 5 (382 days) four of the 15 plants flowered. No more plants came into flower. Florescence ended in second half of November. In October leaves turn yelow and shoots gradually die in the course of November and December (Dormancy period).

Towards end of December development of new rosettes from auxiliary buds on shoots (as in series I).

In the 2nd year of vegetation the plants flowered in summer. This course of development under short day occurred with late summer seeding that is under conditions of "waning light". It would seem therefore, that such a development is due to the fact that the first phases of growth of the plants occurred in conditions most unfavourable to growth (as regards light quantity). Hence the long phase of growth inhibition of the rosette and the consequent course of development. For this reason in 1962 two further series were seeded on April 10 and May 25, some plants under short day, others under natural daylight.

I a b 1 e 2

\begin{tabular}{l|c|c|c|c}
\hline \multirow{2}{*}{$\begin{array}{c}\text { Date } \\
\text { of } \\
\text { measurement }\end{array}$} & \multicolumn{2}{|c|}{$\mathrm{N}$} & \multicolumn{2}{|c}{$\mathrm{S}_{8}$} \\
\cline { 2 - 5 } & $\begin{array}{c}\text { IIumber } \\
\text { of leaves }\end{array}$ & $\begin{array}{c}\text { He1ght } \\
\text { 1n om }\end{array}$ & $\begin{array}{c}\text { Number } \\
\text { of leaves }\end{array}$ & $\begin{array}{c}\text { Height } \\
\text { 1n om }\end{array}$ \\
\hline 9.XI & 18.6 & 10.0 & 14.4 & 4.2 \\
7. XII & 18.6 & 10.3 & 16.0 & 4.2 \\
$28 . X I I$ & 19.6 & 10.3 & 15.6 & 4.2 \\
29.XII & 19.6 & 10.6 & 18.2 & 6.2 \\
8.II & 21.6 & 11.7 & 21.2 & 6.4 \\
8.III & 22.6 & 12.0 & 21.2 & 6.8 \\
\hline
\end{tabular}

S e ries III and IV. Under short day $S_{8}$ - relatively rapid growth of rosette. A part of the plants seeded on April 10 formed short shoots before autumn. Leaves relatively large. In autumn all plants pass through a phase of growth stagnation (Table 2). The "old" leaves begin to dry and 
the shoots gradually die in spring and subsequently new rosette develop from the auxiliary buds.

Under natural daylight $(N)$ the plants develop shoots immediately aru in in autumn they also pass through a period of growth stagnation. In spring - partial drying of "old" leaves (but not the whole shoot) further growth of shoots and differentiation on new leaves. Simultaneous growth of new rosettes from auxiliary buds, extending immediately into shoots (May 3 mean length $23.4 \mathrm{~cm}$ ). No differences in the development of these two series.

A distinct dependence of vegetative development both on daylength and light intensity is evident. Growth inhibition is the response to waning light, under natural changing daylight however, in the phase of growth stagnancy only an inhibition of growth occurs, without the vegetative organs developed in the preceding period dying (Table 2).

The course of development of Cucubalus baccifer in the light of the present experiments may be characterized as follows.

1. Cucubalus belongs to facultatively long-day plants reacting by a considerable acceleration of development to continuous illumination and not requiring vernalization to flower.

2. The development of shoots occurs both under continuous illumination and short day. In the latter case, the rosette phase is protracted and the development of shoots is distinctly related with the seasons of rising light intensity.

3. Under continuous illumination, independently of the intensity and spectral composition of light (thus independently of the season), the developmental processes (growth and changes in the character of differentiation) are continuous. There is no phase of lowered activity (dormancy). The plants grow rapidly and intensively, they extend into shoots, the differentiation and growth of the leaf blades is intensive. Flowering is profuse in the periods of higher light intensity.

4. Under short day there is a distinct cyclization of growth and differentiation in dependence on the quantity (and perhaps quality) of light. The plants enter the autumn and winter period in the stage of a small rosette exhibiting a considerable slowing down (or even stagnation) of growth. In the period of "rising" light conditions intensive growth and differentiation of leaves occur followed by development of shoots. But few plants, however, come into flower in the first year of life. In the autumn and winter period shoots and leaves die and a short period of dormancy sets in. Follows a secondary development of rosettes from auxiliary buds from which shoots develop more rap:dly than in the 1st year of life and florescence occurs in full summer, however, less intensive than under continuous illumination. Thus the development of plants under short day shows a distinct relation to the seasonal changes in light conditions and to plants' age. 
5. Plants seeded in spring under natural daylight, long at the time, develop shoots rapidly. Subsequently however, the waning light conditions, exert an inhibitory influence. The plants do not come into flower in the same vegetative season, but undergo in autumn a phase of growth stagnation.

The formed shoots do not die, they continue to grow in spring and produce flowers. Simultaneously new shoots develop from auxiliary buds.

6. Older plants also preserve their photoperiodic sensitivity and the influence of the anterior exposure to short day is of little consequence.

\section{III}

Some following species, which we had under observations show still greater inhibitions under the short day, than Cucubalus - they are Silene inflata and Dianthus carthusianorum.

Silene inflata (flowers under field conditions in VI-VII). Observations carried out on two series sown on 20th XI.59. and 15th II.1960. (Photo 2).

Combination $L_{24}$ : A short period of rosette rapid development of shoots. Leaves with long petioles, markedly larger than under $S_{8}$. 85 days after sprouting general budding after 110 days (half of January - 1st series) general abundant flowering, lasting about 50 days. The development of plants from the 2nd series was analogous, it allows to conclude about a slight influence of the light intensity (full flowering the end of IV to VI). After 14 months of staying under the short day 5 plants were transferred to the continuous daylight. Very rapid reaction - differentiation of the new leaves - and development of stems. After 3 weeks beginning of budding and flowering less intense, however, than that of plants, which were growing constantly under the continuous dayligh.

The short day exerts a very strong inhibiting influence: the plant develops small rosettes of tiny, skiny, greyish-green leaves. General considerable speed reduction of the differentiation of leaves and their growth.

After more than 8 month (spring of the next year) some plants began to produce thick shoots, several $\mathrm{cm}$ long with a leaf rosette at the end. During the following 2 years the habit of plants grown under the short day remained the same with distinct cyclic seasonal fluctuations: stronger tendencies to the formation of the new leaves in spring of the shortened shoots and leaves in late summer, alternating with the periods of growth stagnation, dying away of leaves and shortened shoots (late autumn, partly in midsummer). In summer $1962-$ several plants died away because of the decay of the root neck - in 


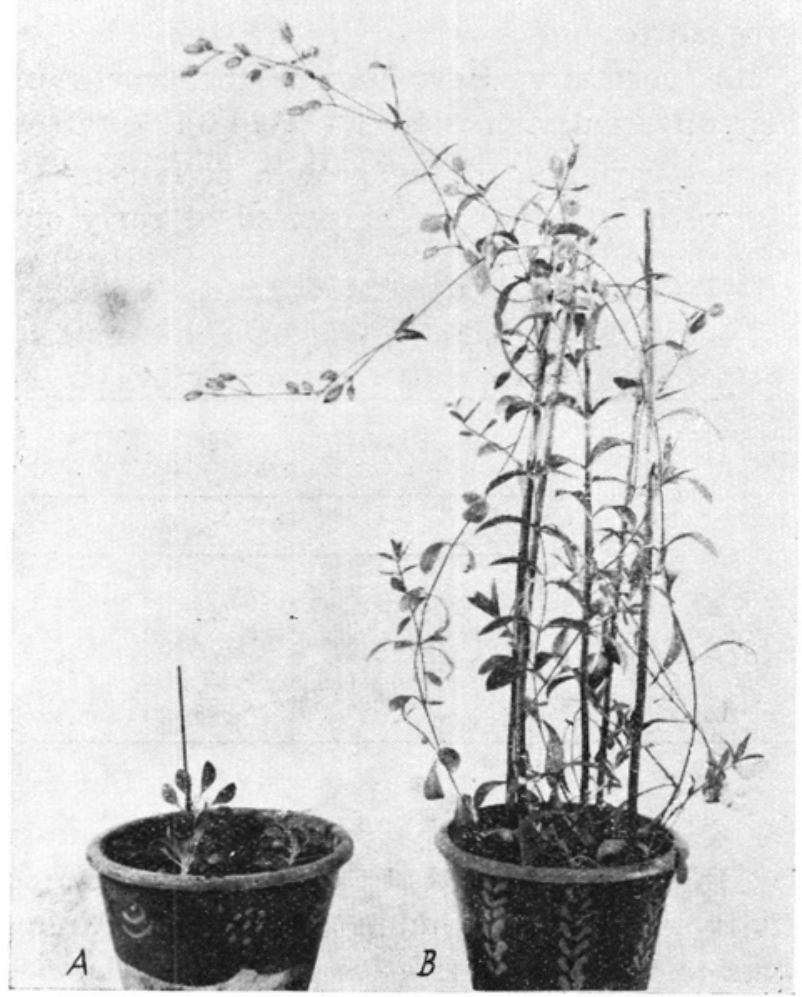

Photo 2. Silene inflata. $A-$ Short day; $B-$ continuous day.

autumn a rapid elongation of the short shoots and coming into flower of 2 plants in a series of 8 was observed.

The abundance of flowering was slight. During the winter 1962/63 three more plants died away (vegetative). In late summer 1963 two plants came into flower for the second time and then two more.

Dianthus carthusianorum (flowering in field conditions VII-VIII) sowing 25.VIII sprouting 4.IX.1959.

Under the continuous daylight first plants came into flower between half of February and the end of April (173rd-227th day after sprouting) - end of flowering in the beginning of July. In the period July September the development of new leaves both of plants which had flowered and of those which had not. In autumn between the end of September and the half of December (380th-470th day after sprouting) all the plants came into flower $(n=15)$, among them 3 for the second time. Lower flowering intensity than under natural conditions.

Under the short day - after more than one year 2 plants produced short shoots - they came into flower forming only several flowers per 
plant - after 600 days one more plant flowered $(20 \%)$. In this period most of plants began to die.

Concerning the vegetative development the leaves under $S_{8}$ were smaller and their differentiation slower (Table 3).

Distinct seasonal variation of the growth activity: - intense differentiation and growth of leaves in the period of early spring and then in midsummer.

T a b 1 e 3

\begin{tabular}{c|c|c|c|c}
\hline $\begin{array}{c}\text { Jumber of days } \\
\text { from sprout 1ng }\end{array}$ & \multicolumn{2}{|c|}{ Number of leaves } & \multicolumn{2}{|c}{$\begin{array}{c}\text { Iength of the } \\
\text { leaf blade }\end{array}$} \\
\hline & $\mathrm{I}_{24}$ & $\mathrm{~S}_{8}$ & $\mathrm{I}_{24}$ & $\mathrm{~S}_{8}$ \\
\cline { 2 - 5 } & 13 & 11 & 8.7 & 1.9 \\
74 & 15 & 10 & 11.8 & 3.1 \\
122 & 19 & 13 & 12.2 & 3.3 \\
\hline
\end{tabular}

Some of the plants flowered in spring - all in autumn - so the "phase of flowering" was divided by a summer period of greater vegetative activity and the maximum of flowering frequency was in autumn. It seems to indicate a negative interaction between the period of intense differentiation and growth of leaves, on one hand and flowering on the other. Facts observed on other plants - and supposed to be due to the inhibiting influence of the young, growing leaves on the flower formation ( $\mathrm{L} \mathrm{ang} 1961$ and cited there further literature first of all De Zeuw 1956; Fisher and Loomis 1957).

Under natural conditions the proper flowering period occurs also in the months of waning light conditions as well as of lower nyctotemperatures (growth inhibiting). In the greenhouse, under the continuous daylight and at higher night temperatures the more and more non-optimal light regimes become the only powerful growth limiting factor - therofore maximum of the flowering frequency moves to the autumn months. The flowering intensity reduced in comparison with natural conditions - was connected with the fact, that the flowering took place in the months with a low light intensity and without interaction with vernalization as an intensifying factor.

According to Chouard (1960) the different species of Dianthus differ markedly one from the other by their reaction to vernalizat:on. Some species are not affected by vernalization, for the others vernalizat:on is a factor which intensifies the generative processes. The others, as $D$. arenarius, growing in h:gher temperatures develop only short shoots - and only few flowers after 2-4 years (development of 
a phenotypical character analogous to that of Silene inflata under the short day). D. carthusianorum according to $\mathrm{Chou}$ a $\mathrm{d}$ belonged to the species, which without vernalization (under the continuous daylight) produced only short, thick leafy shoots, but did not come into flower.

Differences in reaction of $D$. carthusianorum in $\mathrm{Chou}$ ard's and in our observations might result out of the differences in sowing term or day length (with us continuous daylight) as well as out of interaction with other variables e.g. light intensity or temperature. In regard to the frequency, time and intensity of flowering - great fluctuations dependent on the light intensity in interaction with the day length were frequently abserved in our experiments with other plants (e.g. Potentilla supina, Taraxacum officinale, Salvia officinalis - working out not finished).

Such facts are known from literature (R. F. Stinsen and A. Laurie 1954; C. C. Cooper and D. J. W a t s e $n$ 1954). The efficacy of vernalization only under determined light conditions was also established ( $\mathrm{N}$ a p p - Z in n 1962).

There are also plants reacting in a different way under the continuous and long day conditions.

On the other hand, the scale of photoperiodical reaction and even the type of reaction may change in the limits of species in dependence on the origin of the given population.

The observations of Cunning-Bruce (1962) on the photoperiodical reaction of Chenopodium rubrum in dependence on the geographical latitude from which the investigated populations were derived were especially interesting.

Great differences in the "norm" of photoperiodical reaction of barley under the short day were established (R. Takahashi and S. J a s ud a 1960) with the various for different varieties interaction with the light intensity. Those differences vanished under the continuous daylight. A number of data about the variation inside of species are recorded by W. I. R a z u mow (1961).

Optima as well as the scale of reaction may fluctuate between populations in a wide range. Though the differences appear mainly under the not optimal conditions (A g a jew 1962) one is not obliged to assume, that the changes of these "norms" are due to the not optimal conditions, as A g a jew does (1962).

Plantago lanceolata (flowering under natural conditions V-IX) sowing on 7. IX. 1957, all the plants under continuous daylinght came into flower between 135th and 224th day after sprouting, and most of the plants under natural day conditions began to flower between 180th and 224 th day i.e. in summer months. Vernalization intesifies the flowering process (observations on $P$. lanceolata published in one of the previous 
works - R.N.R.81.A.2. 1960). The plants under the short day remained for a long time vegetative. Just in the second, third and fourth year of their life individual plants came into flower 6 from 15 in all i.e. ca $40 \%$. The flowering was slight and of short duration. In the fourth and fifth year most of plants, which did not flower, died because of the decaying of the root neck. Seasonal variation of mean distinctness 2 periods of leaf differentiation and growth II - IV (more intensely) and VII - IX (less intensely), and late autumn - 1st half of winter a phase of growth stagnation.

\section{IV}

Some other species, which were observed by us - under analogous conditions and during the same length of time, did not flower under the short day even sporadically.

Here belonged among others: Chelidonium maius, Nepeta cataria, Polemonium coeruleum, Rumex acetosella, Daucus carota, Achillea millefolium, though they flowered under the long or continuous day in different degree and after different time.

Results of the observations on Centaurium umbellatum, during which a certain number of plants passed into the generative phase due to the interaction with vernalization, were published before (A. Listow sk: and A. Jeśm a now i c z 1962) as well as those on Achillea millefolium (A. Listowski, A. J e śm a now ic z 1960). Results of the observations on $P$. supina - will be given in one of the following publications. Below there are the results of observations on the remaining species.

Nepeta cataria (flowering time under field conditions in field VI-X) sowing on 16th. II. 1960. The general and intense beginning of flowering, of the plants, growing under continuous daylight, between the 70 th and 85th day after sprouting. Under the short day neither flowering nor budding during 14 months. After 250 days (November) some plants were transferred from the short day to the continuous one: they began to flower in 75 days.

On the contrary, the stem development under the short day occurs with only a certain retardation in comparison to $L_{24}$.

In the initial phase of bud formation of the plants comb. $L_{24}$ (18. IV. 55 days after sprouting) the differences in some vegetative features were as follows:

$\begin{array}{lcc} & L_{24} & S_{8} \\ \text { mean - number of leaves } & 22 & 14 \\ \text { mean - height of the main shoot } & 29,5 & 4,5 \\ \text { mean - number of lateral shoots } & 9,0 & 2,0\end{array}$


With the increase of light intensity - the growth rate of the plants $S_{8}$ becomes faster - attaining at the end of July the height of the plants $L_{24}$. The stems much thinner prostrate.

Rumex acetosella (flowering under field conditions IV-VII). Observations carried out in two series on the plants from sowings in August (10.VIII.1959) and in March (15.III.1961) during 21 or 15 months. In both series under the continuous daylight most of plants came into flowers. Abundant flowering, preceded by withering of the rosette leaves - in the period of July up to the late autumn. i.e. after 11 or 17 months.

Under the short day rosette only. In the age of 14 (I ser.) or 19 (II ser.) months the dying away of plants began. Great differences in the habit and generative development. Under the continuous daylight the plants from August sowings - developed during autumn and winter rosettes of long petiolate leaves with very large blades of oblongo - oval shape. More than ten first leaves kept this shape proper to the leaves of juvenile phase - the plants of March series had the leaves slightly smaller, which changed their shape more rapidly into a normal sagittate:

$\mathrm{T}$ a b 1 e 4

\begin{tabular}{l|c|c|c|c}
\hline $\begin{array}{l}\text { Number of days } \\
\text { from sprout1ng }\end{array}$ & \multicolumn{2}{|c|}{110} & \multicolumn{2}{c}{143} \\
\hline Combination & $I_{24}$ & $S_{8}$ & $I_{24}$ & $S_{8}$ \\
\hline $\begin{array}{l}\text { Nean number of leaves } \\
\text { Wean lencth of a blade }\end{array}$ & 70.6 & $\begin{array}{c}13 \\
5.3\end{array}$ & $\begin{array}{l}10 \\
12.1\end{array}$ & $\begin{array}{c}16 \\
6.5\end{array}$ \\
\hline
\end{tabular}

one. Under the short day: small compact rosettes; with shorter but wider, sagittate blades. More rapid leaf differentiation (Table 4) contrary to Nepeta and Cucubalus or Dianthus.

If the "juvenile" leaf shape were also an index of the juvenile phase - the prolonged producing of the "juvenile" leaves under the continuous daylight in series I, as compared with the plants of series II, would be in accord with the observations of $\mathrm{H}$ ig a zy (1962), that the lower light intensity prolongs the juvenile phase, on the other hand the short day plants did not show this correlation - though, the same author and the others indicate the prolonging influence of the short day on the non-inductive juvenile phase of the long day type of plants.

Polemonium coeruleum (Photo 3). (flowering VI-VII). Observations carried out during 2 years on a small number of plants. About a half of plants flowered under the continuous daylight - after 8-12 months with a slight flowering intensity. Under the short day exclusively rosettes. Great differences in the size of leaves and length of petioles - as 


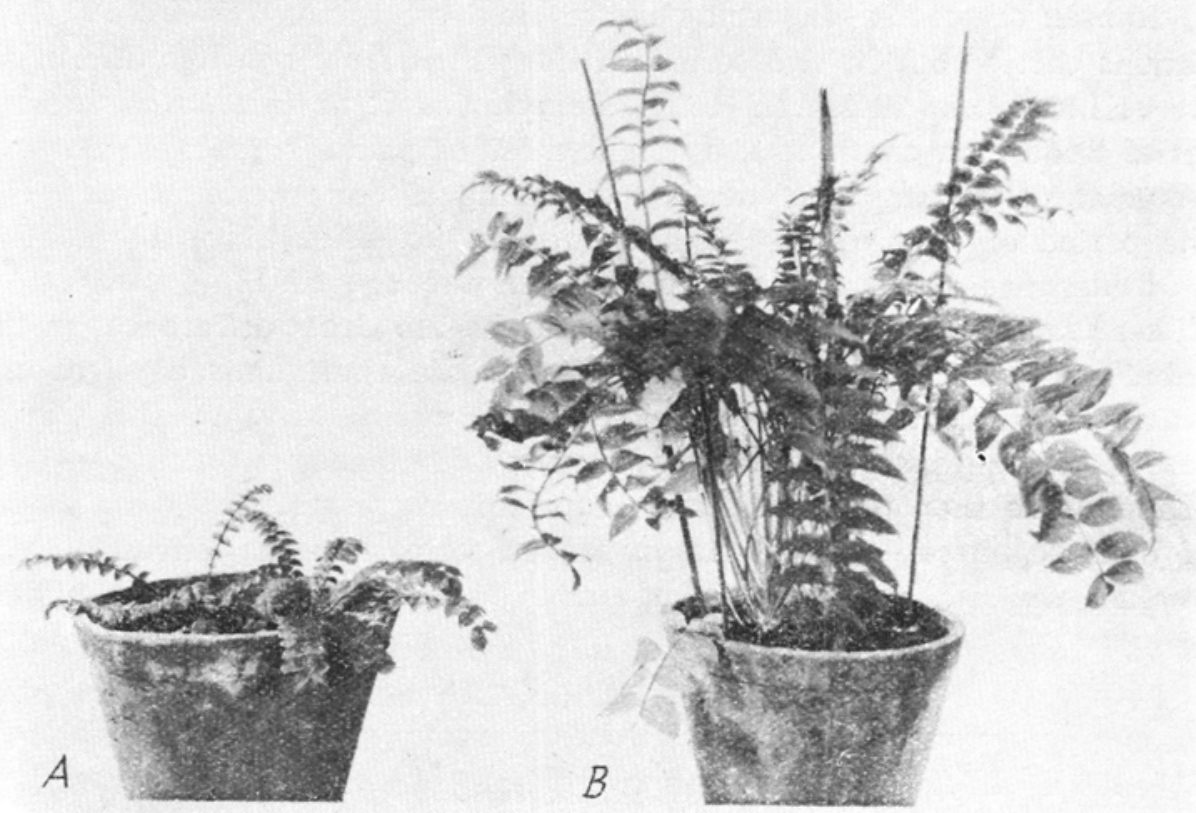

Photo 3. Polemonium coeruleum. A - short day; B continuous day.

well as of the form of rosette between the plants from $L_{24}$ and $S_{8}$. Distinct seasonal fluctuations in the development cycle: phase of intense differentiation of leaves in spring and the second, a slighter one, after flowering - in September. Inhibition of new leaf formation and dying of the older ones - in late autumn.

Daucus carota (flowering under field conditions VI-IX (wild forms from the neighbourhood of Puławy) sowing in February 1960. Vernalization during 30 days - then continuous daylight - uniform and rapid coming into flower of all the plants. Without vernalization: Under the short day exclusively rosettes during $2^{1 / 2}$ years. Under $L_{24}: 2$ plants came into flower in July of the sowing year (130-145 days after sprouting). In the second year 1 plant came into flower in April (406 days), 4 between May and July (430-480 days), 2 in the end of August (540 days) - at last further 2 plants in May 1963 (after more than 3 years) -11 in all from 15 , i.e. above $70 \%$ of the experimental series. The differences in the habit between the rosette under $L_{24}$ and $S_{8}$ were slight.

Chelidonium maius (flowering under field conditions V-IX), sowing on 11/VIII.59. Under the continuous daylight - the first plants formed flower buds 184 days after sprouting (end of February) - to the end 
of March (220 days) $50 \%$ of plants came into flower - to the half of June $80 \%$. The remaining ones did not flower up to the late autumn. The flowering intensity markedly lower than that of the plants growing under the natural conditions. The shoots are short, slightly branched, they do not grow above the leaf surface and develop several flowers each.

Under the short day no flowers during 2 years.

a. In November 1960 - (438 days after sprouting) a part of plants was transported from $S_{8}$ to $L_{24}$; the plants came into flowers between the 75th and 130th day from the moment of transferring to the continuous daylight. The flowering was of very slight abundance and short duration.

b. The plants of the same age from the combination $S_{8}$ - were submitted to 52 days' vernalization, and then placed under the continuous daylight and under the short one. Combination $S_{8}$ (v) $S_{8}$ did not come into flower. On the contrary all the plants $S_{8}(\mathrm{v})-L_{24}$ began to flower between 23rd and 85 th day from the end of vernalization. Abundant flowering. Inflorescences with many flowers. The intensity and course of flowering were near to those of the plants flowering under natural conditions. The leaves of vernalized plants larger than those of the not vernalized ones. On the contrary, the differences of the habit and leaf size between the not vernalized plants $L_{24}$ and the $S_{8}$ ones were relatively little.

\section{DISCUSSIONS AND CONCLUSIONS}

1. Perennial species (except biennial Daucus), the observations on which are described abow, all belong to the plants common in this country. The seeds gathered from the wild plants growing in the environs of Puławy - germinated soon after the gathering. The differences in reaction under the conditions of the experiment were distinct and large, though all these species grow under similar climatic conditions. These differences concerning the 8 species in which the inhibiting influence of the short day has been established - are shortly summarized in Table 5. Potentilla anserina and Ranunculus repens came into flowers with the same intensity independently of the day-length (Potentilla) or only with slightly diminished intensity under the short day (Ranunculus). The remaining 8 species showed a distinct long day reaction, however, of different intensity. Taking into consideration both the rapidity of coming into flower and the intensity of flowering, the continuous daylight seems to be the optimal regime for the intensity of generative process of Silene and Cucubalus. The same is true for Nepeta and Plantago. The remaining 4 species flowered under the con- 


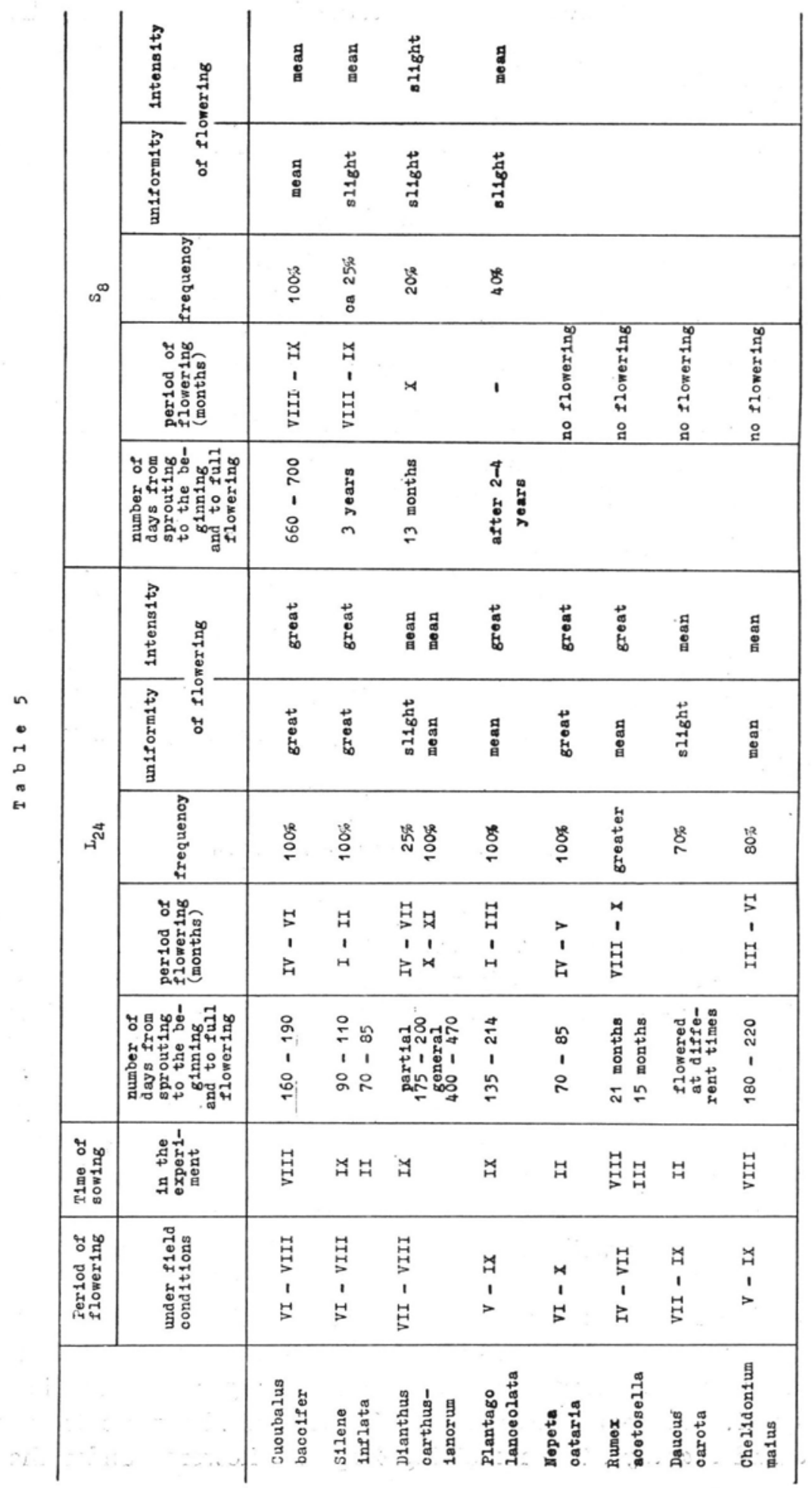


tinuous daylight, but taking into consideration that their coming into flower was not uniform, the intensity of flowering slight and that some plants did not flower at all, one must think that the continuous daylight, though it renders the flowering possible, does not constitute optimal conditions for this process (vide further p. 2).

Concerning the reaction under the short day - in four species the flowering has not been observed - they might be considered as "obligatory" long day plants provided we mean this classification as conventional. In three first species the flowering of a small number (Dianthus, Silene, Plantago) or of all plants (Cucubalus) has been observed after a very long time also under the short day. In a certain sense these species might be considered as facultatively neutral - however with a strong inhibiting effect of the short day upon the development of the generative organs, which were developing gradually after a long time and in interaction with the light intensity.

Under the continuous daylight the accumulation of activators of generative development (e.g. endogenic gibberellines) would occur very quickly, determining the further development.

Under the short day this accumulation would occur very slowly, at the same time other inhibiting factors may exert influence. Seasonal changes of the growth activity under the short day in interaction with light intensity are very distinct - a long period of growth stagnation until the phase of full rest (Cucubalus) is the expression of this fact. Rosette of Cucubalus sown in autumn remains very small during a number of months and does not develop almost at all. Growth activation is connected with the rising light conditions.

Simultaneously the inhibiting influence of leaves active during a long time - may work. The plants "will have no time" to develop generative organs before the return of the next phase of growth stagnation. Moreover a part may be played by the $C / N$ ratio connected with the accumulation of a definite quantity of reserve substances - so the possibility of coming into flower under the short day would be dependent also on the development of the leaf matter - on an adequate length of the period of photosynthetic activity - on root development and amount of organic matter stored in them. All this would be somehow connected with accelerating accumulation of activators of the generative development under the unfavourable for this accumulation conditions of the short day. According to R e jmers (1957) the efficacy of vernalization of some biennial plants depends on the reaching by the root a certain development phase connected with storage of a certain quantum of reserve substances.

2. Under the continuous daylight a certain number of plants of Chelidonium, Daucus and Rumex did not come to flower, the flowering 
intensity was slighter, the shoot growth was also less intense than under the natural conditions (also Dianthus). The continuous day renders the flowering possible, but it is not an optimal regime for these plants from the point of view of generative development (different e.g. from Potentilla supina - and some other species, which were observed by us). In the species Daucus and Chelidonium some plants have been submitted to the influence of lower temperatures, in the interaction with the vernalization a rapid uniform and intense coming into flower occurred. This intensifying influence of lower temperatures upon the generative processes was already observed many times, first of all under the non-optimal light regimes, e.g. at different light intensities or development inhibiting day lenght ( $\mathrm{Lang} 1956$, N a p p-Zinn 1962, K urth 1955, H a g a r 1961, Ka s perbauer Gardner Loomis 1961, S. J. Wellensieck 1960 - also A. Listowski on Potentilla supina).

This intensifying the generative processes influence of the lower temperatures seems to be a frequent phenomenon - however, it has a different range for different species - so the generalization of such a conclusion is not possible.

Melilotus (Kasperbauer Gardner and Loomis), Campanula media (W elle n s i e k), Potentilla supina (A. Listowski), in interaction with vernalization came into flower under the short day. On the contrary the intensifying influence of vernalization upon the generative development of Daucus and Chelidonium was observed only when the plants after the vernalization grew under $L_{24}-$ conditions. while the combination $S_{8}$ (v) $S_{8}$ - did not come into flower.

3. It has been established many times, that the ability of reacting to photoperiodic and vernalization stimuli correlates in certain limits with the plant age (not active juvenile phase, vanishing of the reactivity in connection with growing old), the type of reaction may also undergo changes during the ontogenesis. Concerning the length of the juvenile phase the possibility of its wide modification was established - especially under the conditions of non-optimal and non-inductive light regimes (Hig a z y 1962).

We know relatively little, especially about the perennial plants, how long they can keep the ability of reaction to the day length or to the lower temperatures. Millet, rye and soy bean are thought to loose it with the age fast enough. Sedum after 9 years of exclusively vegetative development under the short day, came into flower after transporting in to the long day ( $\mathrm{R} \mathrm{udorf} \mathrm{1958).}$

In our observations Chelidonium transported 438 days after sprouting to the continuous daylight came into flower very quickly, and still more so in the interaction with vernalization - it allows to judge about the 
retaining of the reaction ability both to the photoperiodic stimulus and to that of low temperatures. Similarly Daucus carota, Silene and Cucubalus have retained their reaction capacity. It seems, that independently of the differences between species which may be large, the plants growing under inhibiting conditions, keep during a very long time the capacity of perception of photoperiodic and vernalization stimuli.

4. The plants growing under continuous daylight differed distinctly from those grown under the short day - by the form of rosette, the dimensions, the colour and often the shape of leaves, the rapidity of differentiation and growth of leaves.

a. Under the continuous daylight - the leaves are long petiolate the blades sometimes markedly larger and of lighter colour, the growing old of leaves more rapid, the habit of rosette more erect.

b. Rumex acetosella - under the continuous daylight more than ten first leaves had blades of an oblongo - oval shape not sagittate. On other plants the diminishing of the leaves under the continuous daylight was observed (Achillea, Hypochoeris - A. Lis towski and A. J eś m a n o w i c z 1960).

Analogous observations on Ipomea ( $\mathrm{N}$ i o k u cit. L a $\mathrm{ng}$ 1956).

c. Nepeta and Cucubalus - developed stems under the short day also. The growth rate was however slower, the internodes shorter, the stems thinner, often prostrate (analogous modifications we have observed on corn-cockle Agrostemma githago and bluebottle (Centaurea cyanus) also. We n t (1957 p. 155) on Poa pratensis, Flemion (1959) on Prunus persica - under the continuous daylight in the light of long waves thin twining shoots and pale-green large leaves in the light of short waves short shoots with dark green leaves.

All these changes in the habit and the shape and size of leaves - are most probably the results not only of the differences of the day length, but also of the changes in the light intensity and spectral composition (W ent 1957). Various influence of the interaction between the light intensity and the day length may occur in different seasons. Independently of the fact, that the leaves are in general larger under the continuous daylight, they are also larger when the share of the red rays increases (R. Powell a M. Griffin 1960).

The differences between the dimensions and shape of leaves of the plants growing under the continuous daylight and those under the short day are larger in the initial development phases when the plants are sown in late summer and grow under the waning light conditions. The degree of reaction is different in different species - in our observations it was stronger in Rumex acetosella and Silene inflata, weaker in Daucus and Chelidonium. Differences between species in the rapidity of leaf differentiation under the continuous day and the short one were also distinct. The measurements of Cucubalus, Nepeta and Dianthus showed 
an accelerated leaf differentiation under the continuous daylight. Rumex, on the contrary, had more rapid differentiation under the short day. The length of the leaf life of all the species was, however, greater under the short day. Haggar (1961), Schwabe (cit. Thom a s 1961, as well as $\mathrm{Th}$ om a s (1961) observed the hastening of the differentiation and growth of leaves under the inductive for the generative development conditions (photoperiodic or vernalization). The period of leaf differentiation, as well as the length of their life undergoes under these conditions a shortening - so after a longer time under the short day the number of leaves becomes greater.

In the experiments of J. Liverman and A. Lang 1956, Hyoscyamus, which under the conditions of low light intensity was induced to flowering by the addition of auxins - developed markedly less leaves than the control plants.

The stress must be laid on the fact, that here also the reactions of various species may be different, causing a different interpretation of this phenomenon (E. B ünnig and Kond 1956).

5. Observations of the annual cycle - show the seasonal variation of the activity of both processes of growth as well as of flowering. The scale of this variation is different in different species (smaller in Chelidonium, Daucus, Nepeta, Rumex Plantago, larger in the remaining ones).

These endogenic rhythms show a distinct interaction with external conditions, which affect the intensity of cyclic changes, on the other hand the young leaves exert an inhibiting influence upon the flowering processes. How complicated is this process in its phenotypic picture, due to this interaction and to the fact that various factors may have different meaning in different phases - it may be proved by the results of Jung's investigations (1963) on the course of flowering of Gerbera jamesonii.

In our investigations, the seasonal changes of activity were weaker under the continuous daylight than under the short day. Silene and Cucubalus under the continuous daylight had in general a very rapid development and it can be said to be continuous even independently of the sowing term. A similar character of continuous growth with vanishing of sesonal fluctuations under the continuous daylight was observed on trees e.g. birch (K. P. Longman a P. F. W a reing 1959).

In the period of growing light regimes - in the second half of winter and in spring - the intensification of the leaf differentiation and growth processes and then of shoot growth takes place (Cucubalus, Nepeta under $S_{8}$ ). During full summer slower growth with withering of the oldest leaves afterwards again a slighter growth intensification (connected with the development of short shoots of plants not flowering 
under the short day - e.g. Silene $S_{8}$ ). In autumn up to the first half of January - the phase of weaker growth or growth stagnation, in connection with an intense dying away of leaves. Potentilla and Cucubalus under short day lose all their leaves for the period of $6-8$ weeks and pass into the phase of full rest.

The shifting of the phase of general flowering of Dianthus to the period of early autumn similarly to Rumex, under the conditions of continuous daylight, would be connected with the phase of increased growth of the new leaves as well as of growing old and withering of the leaves earlier developed. Rumex independently of the sowing time came into flower \pm at the same time, it seems to be the result of the lengthening of the juvenile phase of this plant sown in autumn, it means when the plants pass their first phases under the waning light conditions.

Potentilla and Ranunculus have their flowering periods at different times under the continuous daylight and the short day. It might be considered as the result of a complicated interaction between the light amount in the given period and the phases of slower development of new leaves as well as of growing old of those previously developed, causing the decrease of their inhibitional influence on the processes of flowering.

Institute of Soil Science

(Entered: 30.I.1964.) and Plant Cultivation

Putawy, Poland

\section{REFERENCES}

A g a jew M. G., 1962, D.A.N. Z.S.R.R. 145 (5).

B ünn ing E., Konıd o R., 1956, Planta 44 (9).

Chou ard R., 1960, Ann. Rev. of Plant Physiology 11:213.

Cooper C. C. a. W ats on D. J., 1954, Proc. of the Americ. Soc. of Hortic. Sc. 64. Gummings-Bruce G., 1961, Plant Physiology Suppl. 1.

Flemion F., 1959, Contrib. from Boyce Thompson Institut. 20 (1).

H a g g a r R., 1961, Nature 191 (4793).

H i g a z y M. K. T., 1962, Medel. v.d. Landbouwhogeschool te Wageningen 62 (8).

J ung es W., 1963, Arch. f. Gartenbau 11 (1).

Kurth H., 1955, Der Züchter 26 (3).

L a n g A., 1956, Fortschritte der Botanic 18:289.

L a n g A., 1961, Encyclop. of Pl. Physiol. 14:209.

Listowski A. i J e śm a n ow i c z A., 1960, Roczn. Nauk Roln. 81-A-2 (304)

Listowski A. i J eśm a nowicz A. 1962. Acta Soc. Bot. Pol. 30 (1).

Liverman J. a. Lang A., 1956, Plant Physiology 31.

Longman K. P. a. W a r e in g P. F., 1959, Nature 4704 .

$\mathrm{N}$ a p p-Zinn A., 1962, Die Naturwissenschaften 49 (20).

Powell R. a. Griffith M., 1960, Plant Physiology 85 (2).

R e j m e r s F. E., 1957, Botan. Żurnał 42 (10). 
Rudorf W., 1958, Entwicklungsphysiolog. Grundlag. d. Pflanzenzüeht. Handb.

d. Pflanzenzücht. I.

$\mathrm{R}$ a z u m ow R., 1961, Srieda i razwitie rastienij.

Stinson R. F. a Laurie A., 1954, Proc. of the Americ. Soc. of Hortic. Sc. 64. $\mathrm{T}$ a k a ha s h R. a. J a suda S., 1960, Ber. Ohara. Inst. 11 (3).

T h o m a s R. C., 1961, Nature 189 (4766).

We 11 ensiek S. J., 1960, Medel, v.d. Landbouwhogeschool te Wageningen 60 (7). W e n t F., 1957, The experim. Control of Plant Growth. 155.

\section{Obserwacje nad rozwojem roślin (VII) \\ O rozwoju niektórych roślin wieloletnich}

\section{Streszczenie}

W ciągu kilku lat prowadzono obserwacje nad rozwojem 26 gatunków wieloi dwuletnich, w większości należących do pospolitych gatunków naszej flory.

Analizowano wpływ stałego stosunku dnia do nocy (przy sezonowo zmiennym natężeniu i składzie spektralnym światła) na rozwój wegetatywny i generatywny u niektórych gatunków w interakcji z jaryzacją.

Wyniki dla 10 gatunków podane są w niniejszej pracy.

Stwierdzono znaczne różnice reakcji między gatunkami:

1. Dwa gatunki (Potentilla anserina i Ranunculus repens) można uważać za fotoperiodycznie naturalne.

2. Wszystkie inne wykazały silniejsze lub słabsze zróżnicowanie fotoperiodyczne, przy czym optymalne układy dla szybkości i intensywności procesów kwitnienia - przebiegają albo na dniu ciągłym bez jaryzacji (np. Cucubulus, Silena, Nepeta), albo dopiero $w$ interakcji z jaryzacją, która odgrywa rolę czynnika intensyfikującego przebieg procesów generatywnych (Chelidonium, Daucus).

3. Na dniu krótkim - (vide tab. 5) stopień zahamowania był różny od zupełnego do częściowego.

U Silena po kilku latach część roślin przy silnie zmienionym habitusie całej rośliny doszła do kwitnienia.

Najbardziej interesujący przebieg obserwowano u Cucubulus: w pierwszym roku rozwijają się jedynie rozety wyrastające w pędy wegetatywne, te obumierają jesienią; roślina po przejściu okresu spoczynkowego rozwija nowe rozety, które wyrastają w pędy i zakwitają.

Autorzy omawiają również różnice w rozwoju wegetatywnym w zależności od układów świetlnych oraz sezonową zmienność aktywności roślin występującą zarówno w odniesieniu do różnicowania i wzrostu organów wegetatywnych, jak i procesów kwitnienia. Skala tej zmienności różna jest u różnych gatunków - ogółem wyraźniejsza na dniu krótkim niż ciągłym. U dwóch gatunków (Potentilla i Cucubulus), rośliny w szklarni na dniu krótkim wykazują pełną fazę spoczynkową.

Przy omawianiu wniosków autorzy dyskutują pewne hipotezy, przy pomocy których można by tłumaczyć różnice w reakcji roślin. 